\title{
FLY ASH MAGNETIC ADSORBENT FOR CADMIUM ION REMOVAL FROM AN AQUEOUS SOLUTION
}

\author{
Gabriela BUEMA ${ }^{1}$, Nicoleta LUPU ${ }^{1}$, Horia CHIRIAC ${ }^{1}$, \\ Dumitru Daniel HEREA ${ }^{1}$, Lidia FAVIER ${ }^{2}$, Gabriela CIOBANU $^{3}$, \\ Loredana FORMINTE (LITU) ${ }^{3}$, Maria HARJA ${ }^{3, *}$ \\ *E-mail: mharja@tuiasi.ro
}

Received: Mar. 02, 2021. Revised: Mar. 17, 2021 Accepted: Mar. 26, 2021. Published online: Mar. 31, 2021

\begin{abstract}
The fly ash generated from a Romanian power plant was used as a starting material in this study. The aim of the study was to obtain a low cost material based on the treatment of fly ash with $\mathrm{Fe}_{3} \mathrm{O}_{4}$ for utilization as an adsorbent for cadmium ion removal. The adsorbent that was synthesized was characterized using different techniques. The adsorption process was investigated by the batch technique at room temperature. The quantity of cadmium ion adsorbed was measured spectrophotometrically. The experimental data showed that the material can remove cadmium ions at all three working concentrations. The adsorption capacity increased with an increase in concentration, respectively contact time. The results were analyzed through two kinetic models: pseudo first order and pseudo second order. The kinetics results of cadmium adsorption onto a magnetic material are in good agreement with a pseudo second order
\end{abstract}

model, with a maximum adsorption capacity of $4.03 \mathrm{mg} / \mathrm{g}, 6.73 \mathrm{mg} / \mathrm{g}$, and $9.65 \mathrm{mg} / \mathrm{g}$. Additionally, the pseudo second order model was linearized into its four types. The results indicated that the material obtained show the ability to remove cadmium ions from an aqueous solution.

Keywords: magnetic adsorbent; adsorption; cadmium ions; kinetic study.

\section{INTRODUCTION}

Cadmium ions have a negative effect on human health because of its toxicity (Abbasi et al., 2020; Buema et al., 2020). Many researchers have investigated the possibility of eliminating cadmium ions from an aqueous solution (Bagheri et al., 2019; Es-sahbany et al., 2021). One of the most applied

\footnotetext{
${ }^{1}$ National Institute of Research and Development for Technical Physics, lasi, Romania

2 Université de Rennes, École Nationale Supérieure de Chimie de Rennes, CNRS, ISCR-UMR6226, F-35000

Rennes, France

3 "Gheorghe Asachi" Technical University of lasi, Faculty of Chemical Engineering and Environmental Protection, lasi, Romania
} 
methods to remove cadmium ions is the adsorption process (Sun et al., 2019; Yang et al., 2018; Yilmaz et al., 2020; Zhang et al., 2021). For example, hydroxyapatite porous materials were used as adsorbents for cadmium removal (Ramdania et al., 2020). Yaacoubi et al. studied the removal of cadmium from water using a natural phosphate as an adsorbent (Yaacoubi et al., 2014). Biochars Produced from Agro-Residues adsorbents were studied by the research group of López et al. (2020). Also, the literature shows studies about recycling fly ash in adsorption domain, taking into account that the unused fly ash presents a problem (specifically, the modified fly ashes as adsorbent were investigated (Harja et al., 2015; Mushtaq et al., 2019; Buema et al., 2020; Huang et al., 2020).

In the last period, of particular interest among the adsorbents presented in the literature are magnetic materials based on fly ash. An advantage of the synthesized adsorbent is that it is easily separated from the aqueous solution using an external magnet.

The properties of fly ash were combined with the properties of $\mathrm{Fe}_{3} \mathrm{O}_{4}$ in order to obtain a good magnetic adsorbent. Therefore, the aim of this study was to evaluate the ability of one material obtained from fly ash treated with $\mathrm{Fe}_{3} \mathrm{O}_{4}$ to be used in the cadmium ion adsorption process. The obtained product was analysed through morphological, chemical, physical, and magnetic properties.

The capacity of this material for cadmium adsorption was discussed as a function of the initial concentration and contact time. Kinetic data were evaluated with the pseudo first order model and pseudo second order model (four types of its linearization).

\section{MATERIALS AND METHODS}

The fly ash used in this research was collected from CET II Holboca, located in Iasi, North-East Romania. $\mathrm{Fe}_{3} \mathrm{O}_{4}$ was purchased from Alfa Aesar and used without any pre-treatment. All chemical reagents were analytical grade and used as received.

\section{Material synthesis}

The adsorbent was prepared as described in a previous work (Harja et al., 2021). Fly ash was used as the starting material. The adsorbent was prepared by mixing the fly ash with $\mathrm{Fe}_{3} \mathrm{O}_{4}$; a ratio of 9/1 Fly ash $/ \mathrm{Fe}_{3} \mathrm{O}_{4}$ was used. The contact time of the synthesis was $4 \mathrm{~h}$.

It should be noted that the adsorbent synthesized is quickly separated from the aqueous solution by an external magnetic field.

\section{Material characterization}

The obtained adsorbent was characterized before the adsorption study. Thus, several techniques were applied for the characterization: SEM, EDAX, XRD, FTIR, BET surface area, and VSM.

\section{Adsorption experiments}

The initial cadmium solutions were prepared by diluting a stock cadmium nitrate tetrahydrate solution $(500 \mathrm{mg} / \mathrm{L})$ with distilled water.

Two adsorption conditions, such as initial cadmium concentration and contact time, were used in order to study the cadmium adsorption capacity and cadmium removal efficiency, respectively.

The experiments were performed at laboratory room temperature, a $\mathrm{pH}$ of 5 in 


\section{Gabriela BUEMA ET AL.}

the Erlenmeyer flasks containing $25 \mathrm{~mL}$ of solution with an initial cadmium concentration of $50 \mathrm{mg} / \mathrm{L}, 70 \mathrm{mg} / \mathrm{L}$, and $100 \mathrm{mg} / \mathrm{L}$, and $20 \mathrm{mg}$ of the adsorbent. The prepared material was withdrawn from the aqueous solutions, and the cadmium concentration in the supernatant was analyzed using a UV-vis spectrophotometer at $576 \mathrm{~nm}$ using xylenolorange $\left(\mathrm{C}_{31} \mathrm{H}_{28} \mathrm{~N}_{2} \mathrm{Na}_{4} \mathrm{O}_{13} \mathrm{~S}\right)$. The experiments were performed with intermittent stirring.

The parameters used in this experiment are presented in Table 1.

Table 1 - Parameters used in the batch experiments

\begin{tabular}{ll}
\hline Parameter & Value \\
\hline $\mathrm{pH}$ & 5 \\
\hline Adsorbent dose & $20 \mathrm{mg} / 25 \mathrm{~mL}$ \\
\hline $\begin{array}{l}\text { Initial Concentration, } \\
\mathrm{mg} / \mathrm{L}\end{array}$ & $50,70,100$ \\
\hline Contact time, min & $5-120$ \\
\hline Temperature, ${ }^{\circ} \mathrm{C}$ & 25 \\
\hline
\end{tabular}

The cadmium adsorption capacity, $q$ (mg/g), was calculated using Eq. (1):

$$
q=\frac{\left(C_{0}-C_{e}\right) V}{m}
$$

The cadmium removal efficiency, $\mathrm{R}$ (\%), was calculated using Eq. (2):

$$
R=\frac{\left(C_{0}-C_{e}\right) V}{C_{0}} \times 100
$$

where, $C_{0}$ and $C_{e}$ are the initial and equilibrium cadmium concentrations $(\mathrm{mg} / \mathrm{L}), q$ is the amount of cadmium adsorbed onto the adsorbent $(\mathrm{mg} / \mathrm{g}), V$ represents the volume of cadmium solution (L), $m$ is the quantity of adsorbent $(\mathrm{g})$.

\section{RESULTS AND DISCUSSION}

\section{Characterization of adsorbent}

The comprehensive characterization of the adsorbent can be found in the literature (Harja et al., 2021). An overview of the material characterization is presented below (Fig. 1).
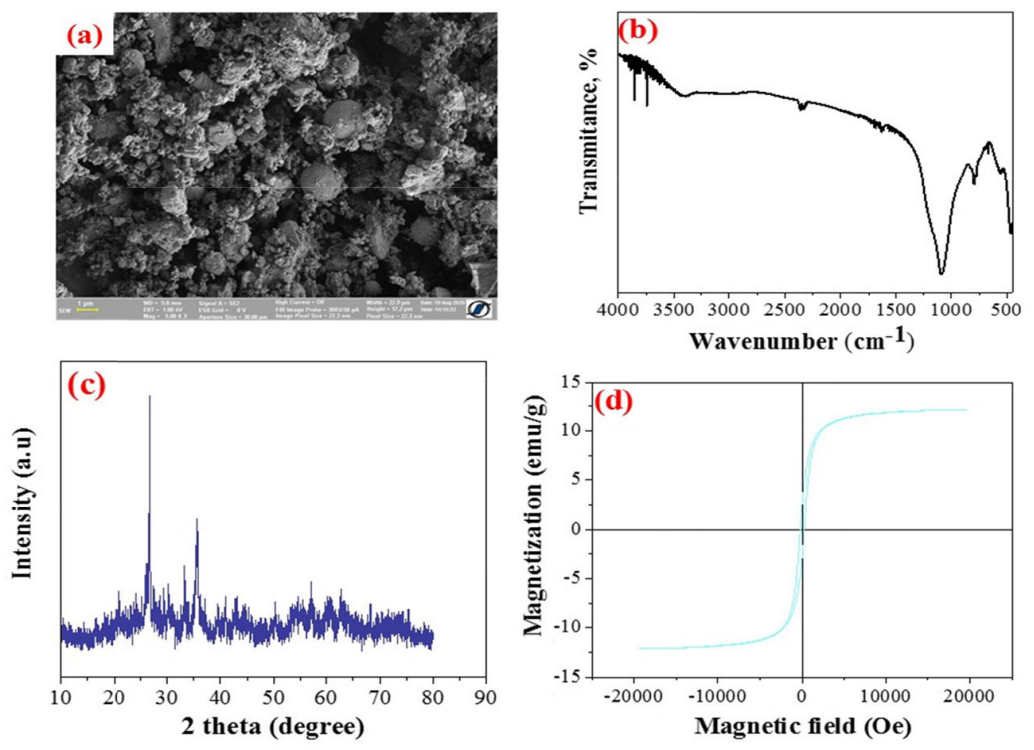

Figure 1 - Adsorbent characterization (a) SEM analysis;

(b) FTIR analysis; (c) XRD analysis; (d) VSM analysis 


\section{FLY ASH MAGNETIC ADSORBENT FOR CADMIUM ION REMOVAL FROM AN AQUEOUS SOLUTION}

The surface area of the adsorbent is $6.153 \mathrm{~m}^{2} / \mathrm{g}$, while the chemical composition obtained through EDAX analysis revealed that the adsorbent contains C: $18.25 \%, \mathrm{O}: 46.72 \%, \mathrm{Si}$ : 13.95\%, Al: $10.22 \%$, Ca: $1.7 \%$, Fe: 7.74\%, K: $0.41 \%$, Mg: $0.34 \%$, Ti: $0.67 \%$.

\section{Kinetic study}

The establishment of the time needed to reach equilibrium in the adsorption process is essential in wastewater treatment applications. The parameters for the design of adsorption devices can be established through the results of the kinetic study. The influence of contact time was studied at three different

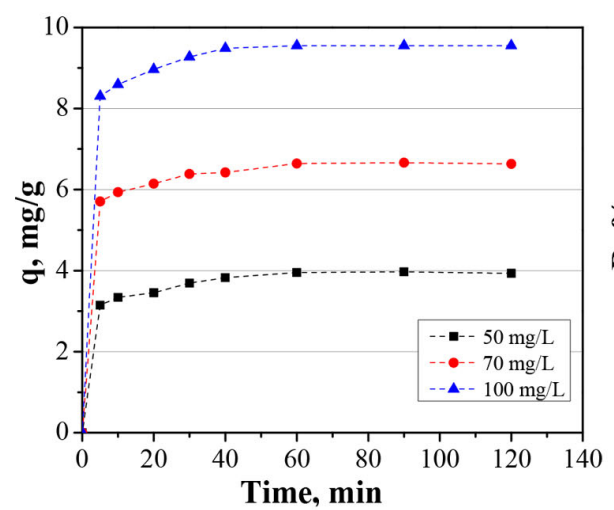

Figure 2 - Cadmium adsorption as a function of the initial concentration and contact time

The data obtained in the batch experiments at $50 \mathrm{mg} / \mathrm{L}, 70 \mathrm{mg} / \mathrm{L}$, and $100 \mathrm{mg} / \mathrm{L}$ were analyzed for the best fit through two kinetic models: pseudo first order and pseudo second order (Buema et al., 2020), which are graphically represented in Fig. 3. The calculated parameters are presented in Table 2. From Table 2, it can be seen that the $\mathrm{k}_{1}$ values calculated from the concentrations. The study was conducted with $20 \mathrm{mg} / 25 \mathrm{~mL}$ dose of adsorbent, a pH value of 5, $120 \mathrm{~min}$ contact time, and a temperature of $25^{\circ} \mathrm{C}$ with intermittent stirring. The results are presented in Fig. 2. This shows that there is an increase in adsorption capacity when the initial cadmium concentration was increased from $50 \mathrm{mg} / \mathrm{L}$ to $70 \mathrm{mg} / \mathrm{L}$ and $100 \mathrm{mg} / \mathrm{L}$. On the other hand, the adsorption capacity was increased by increasing the contact time from 5 to $120 \mathrm{~min}$. Also, the results show that the equilibrium is reached quickly (in approx. $45 \mathrm{~min}$ of contact time). This fact can be attributed to the active sites of the adsorbent surface.

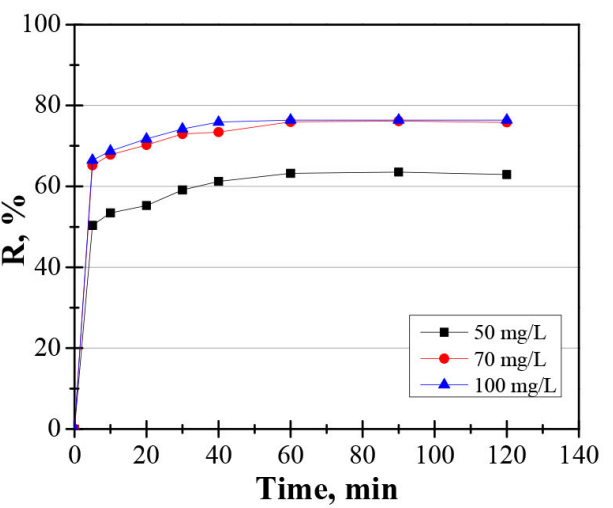

pseudo first order model for cadmium adsorption onto the prepared material were $0.0552,0.0442$, and 0.0796 . The $\mathrm{k}_{2}$ values were $0.1168,0.1064$, and 0.0976 . The calculated adsorption capacity is consistent with the experimental data. Based on the correlation coefficient, $\mathrm{R}^{2}$, it can be stated that the kinetic data are better fit through the pseudo second order 


\section{Gabriela BUEMA ET AL.}

model (Pashai Gatabi et al., 2016; Kahrizi et al., 2018), with a maximum adsorption capacity of $4.03 \mathrm{mg} / \mathrm{g}, 6.73$ $\mathrm{mg} / \mathrm{g}$, and $9.65 \mathrm{mg} / \mathrm{g}$. Additionally,

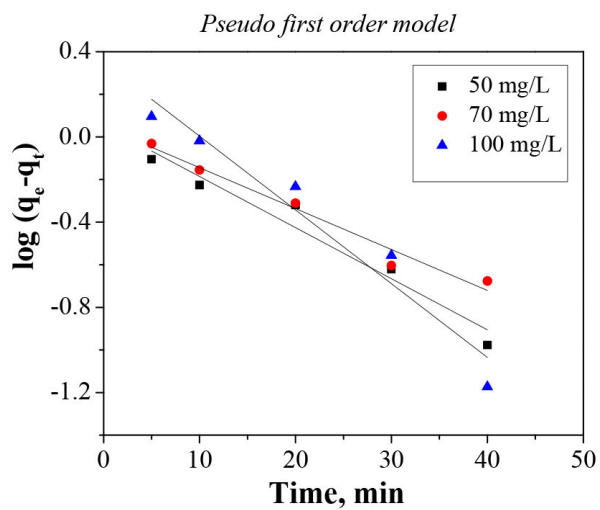

the pseudo second order model was linearized in its four linearization types, Fig. 4 (a-c).

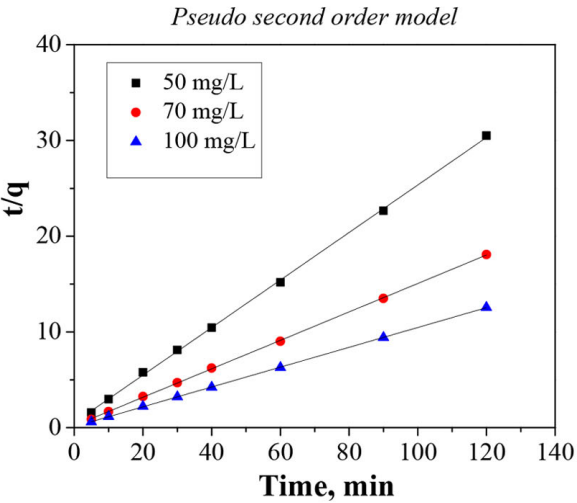

Figure 3 - Adsorption kinetics for cadmium

Table 2 - Kinetic parameters of cadmium adsorption

\begin{tabular}{cccccccc}
\hline $\begin{array}{c}\text { Initial cadmium } \\
\text { concentration }\end{array}$ & \multicolumn{2}{c}{$\begin{array}{c}\text { Pseudo first } \\
\text { order model }\end{array}$} & \multicolumn{3}{c}{ Pseudo second order model } \\
\hline & $\mathrm{k}_{1}, 1 / \mathrm{min}$ & $\mathrm{R}^{2}$ & $\begin{array}{c}\mathrm{q}_{\mathrm{e}} \text { exp, } \\
\mathrm{mg} / \mathrm{g}\end{array}$ & $\begin{array}{c}\mathrm{q}_{\mathrm{e}} \mathrm{cal}, \\
\mathrm{mg} / \mathrm{g}\end{array}$ & $\begin{array}{c}\mathrm{k}_{2}, \mathrm{~g} / \mathrm{mg} \\
\mathrm{min}\end{array}$ & $\mathrm{R}^{2}$ \\
\hline $50 \mathrm{mg} / \mathrm{L}$ & 0.0552 & 0.9563 & 3.93 & 4.03 & 0.1168 & 0.9996 \\
\hline $70 \mathrm{mg} / \mathrm{L}$ & 0.0442 & 0.9722 & 6.63 & 6.73 & 0.1064 & 0.9999 \\
\hline $100 \mathrm{mg} / \mathrm{L}$ & 0.0796 & 0.9463 & 9.55 & 9.65 & 0.0976 & 0.9999 \\
\hline
\end{tabular}
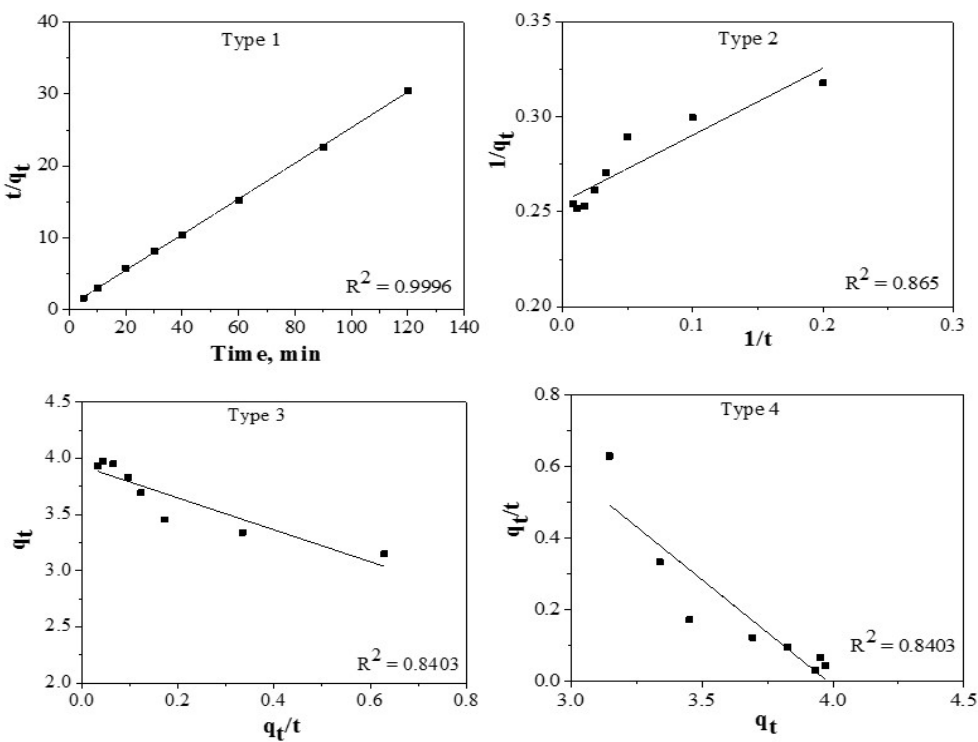

(a) Initial cadmium concentration $=\mathbf{5 0} \mathrm{mg} / \mathrm{L}$ 

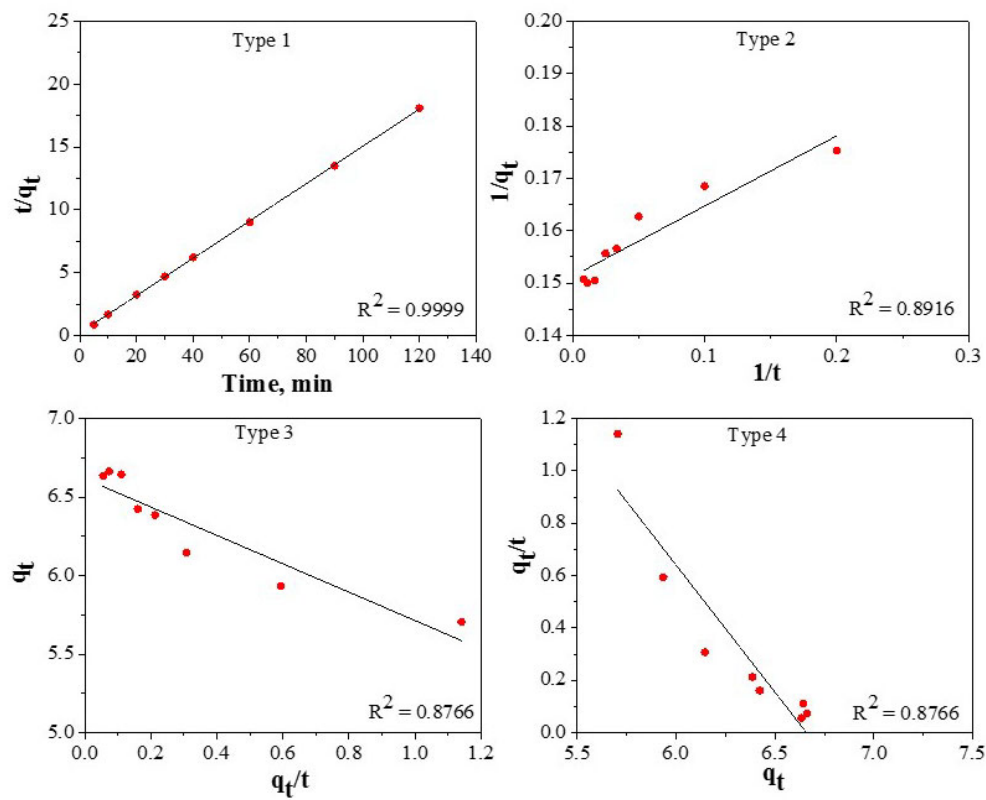

(b) Initial cadmium concentration $=70 \mathrm{mg} / \mathrm{L}$
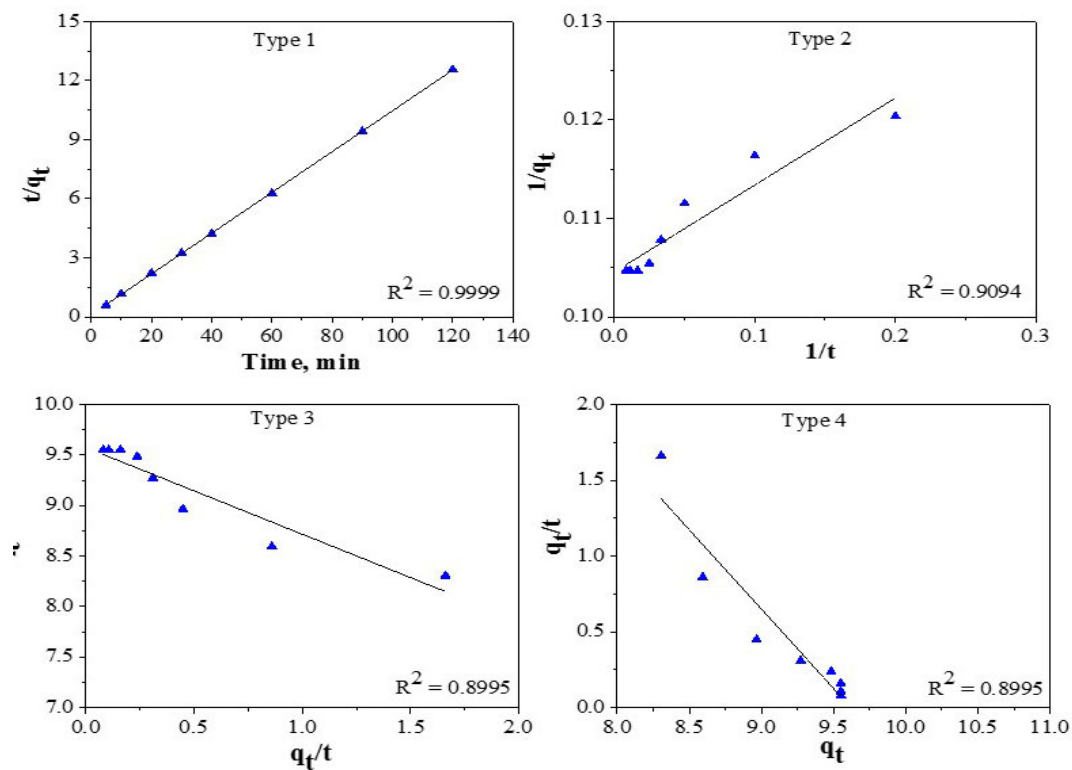

(c) Initial cadmium concentration $=100 \mathrm{mg} / \mathrm{L}$

Figure 4 - Pseudo second order model Type 1 - Type 4 


\section{Gabriela BUEMA ET AL.}

This model was linearized into four forms (Type 1 - Type 4) in order to make a comparison between the differences that occur from the application of the linear regression method to kinetic data. It should be noted that the most popular linear form used in the specialized literature is Type 1. Table 3 reports the data.

From Table 3, it can be seen that the values of the $k$ parameter obtained from the four linear forms are different. The correlation coefficient value, $\mathrm{R}^{2}$, of Linear Type 1 shows the highest result. The other three types of the pseudo second order model exhibited an unfavorable fit between linearized versions with the experimental data, the $\mathrm{R}^{2}$ values being lower compared with Type 1. Based on the results obtained, it can be stated that is not recommended to estimate the pseudo second order parameters by Type 2, 3, and 4 . Consequently, Type 1 is able to represent the cadmium adsorption onto the prepared material.

Table 4 shows a comparison of the cadmium adsorption capacities reported in the literature and those obtained for the magnetic material prepared in this study.

Table 3 - Pseudo second order kinetic parameters obtained from the linear forms

\begin{tabular}{|c|c|c|c|c|}
\hline \multirow{2}{*}{$\begin{array}{c}\text { Kinetic } \\
\text { model }\end{array}$} & \multirow{2}{*}{ Parameters } & \multicolumn{3}{|c|}{ Values } \\
\hline & & $50 \mathrm{mg} / \mathrm{L}$ & $70 \mathrm{mg} / \mathrm{L}$ & $100 \mathrm{mg} / \mathrm{L}$ \\
\hline \multirow[t]{3}{*}{ Type I } & $q_{e}(\mathrm{mg} / \mathrm{g})$ & 4.03 & 6.73 & 9.65 \\
\hline & $k(\mathrm{~g} / \mathrm{mg} \min )$ & 0.1168 & 0.1064 & 0.0976 \\
\hline & $\mathrm{R}^{2}$ & 0.9996 & 0.9999 & 0.9999 \\
\hline \multirow[t]{3}{*}{ Type II } & $q_{e}(\mathrm{mg} / \mathrm{g})$ & 3.92 & 6.61 & 9.57 \\
\hline & $k(\mathrm{~g} / \mathrm{mg} \mathrm{min})$ & 0.1852 & 0.1707 & 0.1234 \\
\hline & $\mathrm{R}^{2}$ & 0.865 & 0.8916 & 0.9094 \\
\hline \multirow[t]{3}{*}{ Type III } & $q_{e}(\mathrm{mg} / \mathrm{g})$ & 3.93 & 6.62 & 9.57 \\
\hline & $k(\mathrm{~g} / \mathrm{mg} \min )$ & 0.3614 & 0.1365 & 0.0897 \\
\hline & $\mathrm{R}^{2}$ & 0.8403 & 0.8766 & 0.8995 \\
\hline \multirow[t]{3}{*}{ Type IV } & $q_{e}(\mathrm{mg} / \mathrm{g})$ & 3.98 & 6.66 & 9.62 \\
\hline & $k$ (g/mg min) & 0.1485 & 0.1457 & 0.1089 \\
\hline & $\mathrm{R}^{2}$ & 0.8403 & 0.8766 & 0.8995 \\
\hline
\end{tabular}

Table 4 - Summary of cadmium adsorption capacity from selected studies

\begin{tabular}{|c|c|c|}
\hline Adsorbent & $\mathrm{q}, \mathrm{mg} / \mathrm{g}$ & References \\
\hline Magnetic biochar composite & $1.67 ; 2.74 ; 2.95$ & Reddy and Lee, 2014 \\
\hline $\begin{array}{l}\text { Iron oxide nanoparticles with } \\
\text { tangerine peel extract }\end{array}$ & 10.9 & Ehrampoush et al., 2015 \\
\hline $\begin{array}{l}\text { BC600, BC } 800, \text { MBC600-0.6300, } \\
\text { MBC800-0.6300 }\end{array}$ & $\begin{array}{l}10.82 ; 13.02 \\
24.32 ; 39.26\end{array}$ & Khan et al., 2020 \\
\hline $\begin{array}{l}\text { Imogolite, Magnetite, Imo-Fe25, } \\
\text { Imo-Fe50 }\end{array}$ & $\begin{array}{l}9.1 ; 13.1 ; 17.4 ; \\
22.7\end{array}$ & $\begin{array}{l}\text { Arancibia-Miranda et al., } \\
2020\end{array}$ \\
\hline $\mathrm{Fe}_{3} \mathrm{O}_{4}$-chitosan composite & $\begin{array}{l}\text { 4.78; } 9.34 ; 13.69 ; \\
17.85\end{array}$ & Rai et al., 2021 \\
\hline Deposited silt & 0.0453 & $\begin{array}{l}\text { Korake and Jadhao, } \\
2021\end{array}$ \\
\hline $\mathrm{FA} / \mathrm{Fe}_{3} \mathrm{O}_{4}$ & $4.03 ; 6.73 ; 9.65$ & Current study \\
\hline
\end{tabular}


It must be emphasized that the adsorption conditions were different. From Table 4, it can be seen that the magnetic material obtained shows good adsorption capacity.

\section{CONCLUSION}

This research presents preliminary results of an ongoing study regarding cadmium adsorption using a low cost magnetic material based on fly ash. On the basis of the results, the following conclusions can be drawn:

The adsorbent synthesized was characterized using six basic techniques.

The influence of two parameters, initial cadmium concentration and contact time, were investigated for the cadmium adsorption experiments performed in this study. The results show that the adsorption of cadmium ion on the adsorbent surface is dependent on the contact time and initial concentration.

The study reported that using the proposed working conditions, cadmium ions were removed with an adsorption capacity of $4.03 \mathrm{mg} / \mathrm{g}, 6.73 \mathrm{mg} / \mathrm{g}$, and $9.65 \mathrm{mg} / \mathrm{g}$, respectively.

The results were fitted using two kinetic models. The $\mathrm{R}^{2}$ values for the pseudo second order model were higher compared to the pseudo first order model for all three working concentrations. Consequently, it can be stated that the chemical adsorption process is predominant.

The overall results suggest that a magnetic material can be used as a low cost adsorbent for treating aqueous solutions polluted with cadmium ions.

Acknowledgment. This work is funded by the UEFISCDI Agency through Project PN-III-P1-1.2-PCCDI-2017-0152 (Contract No. 75PCCDI/2018).

\section{REFERENCES}

Abbasi, H., Salimi, F. \& Golmohammadi, F. (2020). Removal of cadmium from aqueous solution by nano composites of bentonite/ $/ \mathrm{TiO}_{2}$ and bentonite/ZnO using photocatalysis adsorption process. Silicon, 12: 2721-2731. https://doi.org/10.1007/ s12633-019-00372-6

Bagheri, S., Amini, M.M., Behbahani, M. \& Rabiee, G. (2019). Low cost thiolfunctionalized mesoporous silica, $\mathrm{KIT}-6-\mathrm{SH}$, as a useful adsorbent for cadmium ions removal: A study on the adsorption isotherms and kinetics of KIT-6-SH. Microchem.J., 145: 460-469. https://doi.org/10.10 16/j.microc.2018.11.006

Buema, G., Lupu, N., Chiriac, H., Roman, T., Porcescu, M., Ciobanu, G., Burghila, D.V. \& Harja, M. (2020). Eco-Friendly materials obtained by Ffy ash sulphuric activation for cadmium ions removal. Materials, 13(16): 3584. https://doi.org/10.3390/ma13 163584

Buema, G., Harja, M., Lupu, N., Chiriac, H., Forminte, L., Ciobanu, G., Bucur, D. \& Bucur, R.D. (2021). Adsorption performance of modified fly ash for copper ion removal from aqueous solution. Water, 13: 207. https://doi.org/10.3390/w13020207

Es-sahbany, H., El Hachimi, M.L., Hsissou, R., Belfaquir, M., Essahbany, K., Nkhili, S., Loutfi, M. \& Elyoubi, M.S. (2021). Adsorption of heavy metal (Cadmium) in synthetic wastewater by the natural clay as a potential adsorbent (Tangier-Tetouan-Al HoceimaMorocco region). Materials Today: 
Proceedings. https://doi.org/10.1016/ j.matpr.2020.12.1102

Harja, M., Buema, G., Bulgariu, L., Bulgariu, D., Sutiman, D.M. \& Ciobanu, G. (2015). Removal of cadmium (II) from aqueous solution by adsorption onto modified algae and ash. Korean J.Chem.Eng., 32: 1804-1811. https://doi.org/10.1007/ s11814-015-0016-z

Harja, M., Buema, G., Lupu, N., Chiriac, H., Herea, D.D. \& Ciobanu, G. (2021). Fly ash coated with magnetic materials with improved adsorption capacities. Materials, 14: 63. https://doi.org/10.3390/ma14010063

Huang, X., Zhao, H., Hu, X., Liu, F., Wang, L., Xin Zhao, X., Gao, P. \& Ji, P. (2020). Optimization of preparation technology for modified coal fly ash and its adsorption properties for $\mathrm{Cd}^{2+}$. J.Hazard.Mater., 392: 12246. https://doi.org/10.1016/ j.jhazmat.2020.122461

Kahrizi, P., Mohseni-Shahri, F.S. \& Moeinpour, F. (2018). Adsorptive removal of cadmium from aqueous solutions using $\mathrm{NiFe}_{2} \mathrm{O}_{4} /$ hydroxyapatite/graphene quantum dots as a novel nano-adsorbent. $J$. Nanostructure Chem., 8: 441-452. https://doi.org/10.1007/s40097-0180284-3

López, J.E., Builes, S., Heredia Salgado, M.A., Tarelho, L.A.C., Arroyave, C., Aristizábal, A. \& Chavez, E. (2020). Adsorption of cadmium using biochars produced from agro-residues. J.Phys.Chem. C, 124(27): 14592-14602.

Mushtaq, F., Zahid, M., Bhatti, I.A., Nasir, S. \& Hussain, T. (2019). Possible applications of coal fly ash in wastewater treatment. J.Environ. Manage., 240: 27-46. https://doi.org/ 10.1016/j.jenvman.2019.03.054

Pashai Gatabi, M., Milani Moghaddam, H. \& Ghorbani, M. (2016). Efficient removal of cadmium using magnetic multiwalled carbon nanotube nanoadsorbents: equilibrium, kinetic, and thermodynamic study. J. Nanoparticle Res., 18: 189. https:// doi.org/10.1007/s11051-016-3487-x

Ramdania, A., Kadechea, A., Adjdirb, M., Talebc, Z., Ikhoua, D., Talebc, S. \& André Deratani, A. (2020). Lead and cadmium removal by adsorption process using hydroxyapatite porous materials. Water Pract.Technol., 15(1): 130. https://doi.org/10.2166/wpt.2020.003

Sun, H., Xia, N., Liu, Z., Kong, F. \& Wang, S. (2019). Removal of copper and cadmium ions from alkaline solutions using chitosan-tannin functional paper materials as adsorbent. Chemosphere, 236: 124370. https://doi.org/10.1016/j.che mosphere.2019.124370

Yaacoubi, H., Zidani, O., Mouflih, M., Gourai, M. \& Sebti, S. (2014). Removal of Cadmium from water using Natural phosphate as Adsorbent. Procedia Eng., 83: 386393. https://doi.org/10.1016/j.proeng. 2014.09.039

Yang, T., Sheng, L., Wang, Y., Wyckoff, K.N., He, C. \& He, Q. (2018). Characteristics of cadmium sorption by heat-activated red mud in aqueous solution. Sci.Rep., 8: 1355. https://doi. org/10.1038/s41598-018-31967-5

Yilmaz, E., Erenler, F.M. \& Boztuğ, A. (2020). Synthesis and modification of amine-terminated maleic anhydride butyl acrylate copolymer and investigation of adsorption properties for cadmium (II) ions $\left(\mathrm{Cd}^{2+}\right)$. J.Mol.Struct., 1222:128924. https://doi.org/10.1016/j.molstruc.20 20.128924

Zhang, D., Zhang, K., Hu, X., He, Q., Yan, J. \& Xue, Y. (2021). Cadmium removal by $\mathrm{MgCl}_{2}$ modified biochar derived from crayfish shell waste: Batch adsorption, response surface analysis and fixed bed filtration. J.Hazard.Mater., $\quad$ 408:124860. https://doi.org/10.1016/j.jhazmat.202 0.124860 . 